Auf die spezielle Stimulationstechnik bei Kleinstkindern wird eingegangen.

Abschließend wird eine telefonische Überwachungsanlage für Schrittmacherpatienten demonstriert, wobei eine direkte telefonische EKG-Utbertragung vom Dominikus-Krankenhaus, Düsseldorf, in den Kongreßsaal nach München erfolgt.

\title{
172. Chirurgisch-technische Aspekte und Komplikationen bei Schrittmacherimplantationen
}

\author{
E. D. SchwILdEN * und W. Vogels-Aachen
}

Aspects of Surgical Technique and Complications in the Implantation of Cardiac Pacemakers

Summary. Based on our own experience with trans-venous implantation of pacemakers we can state that with the aid of thin, elastic stimulation catheters which can be positioned in the heart and fixed by barbed hooks, it is possible to overcome one technical problem of pacemaker implantation, namely, dislocation of the electrodes, or at least to make the problem less difficult to solve.

Zusammenfassung. Auf Grund unserer eigenen Erfahrungen mit der transvenösen Schrittmacherimplantation stellen wir fest, daB wir in der gezielten Anwendung dünner, elastiseher, durch Widerhaken intrakardial fixierbarer Stimulationskatheter eine Möglichkeit sehen, ein technisches Problem der Schrittmacherimplantation, nämlich die Elektrodendislokation, zu lösen oder zumindest unproblematischer zu gestalten.

\section{Spätkomplikationen der Herzschrittmachertherapie und ihre Behandlung}

\author{
U. KIRSCH*, P. KaLmaR, G. RodewaLd \\ und K.-W. Westermann-Hamburg
}

\section{Late Complications Resulting from Heart-Pacemaker Therapy and the Treatment thereof}

Summary. Heart-pacemaker therapy is performed in a group of patients after a standardized protocol. Incidence and type of late complications are reported. The procedure of placing an intracardiac Elema electrode is followed by $15 \%$ early and $5-8 \%$ late complications. As frequently, late complications of the pacemaker pocket are seen, the total number of these ranging much higher, as on average 3 pacemakers are implanted for 1 electrode. Estimations show that every fourth patient will have a complication during his life time and that this will be life-threatening in $8 \%$ of all patients.

Zusammenfassung. Es wird von den bei Durchführung der Schrittmachertherapie mit einem standardisierten Verfahren an einer größeren Gruppe von $\mathrm{Pa}$. tienten beobachteten Spätkomplikationen berichtet. Die mit einer Frühkomplikationsrate von $15 \%$ behaftete Prozedur der Verlegung einer Elemaelektrode hat eine 